\title{
Political Primordialism Post-Reformation in Indonesia
}

\author{
M. Najib Husain ${ }^{1 *}$, La Husen Zuada ${ }^{2}$, Dewi Anggraini ${ }^{3}$ \\ Universitas Halu Oleo, Kendari, Indonesia ${ }^{1,2,3}$ \\ \{najib_75husain@uho.ac.id ${ }^{1}$ \}
}

\begin{abstract}
This paper aims to describe the practice of political primordialism after the reform era in Indonesia. The method used in this paper is library analysis (reseaach library). Data analysis was performed based on secondary data collected from books, scientific journals and research reports. This paper finds that political primordialism is depicted very strongly in the electoral political competition in postreform Indonesia. The local elections that took place in the reform era were increasingly colored by the priority of native sons, the removal of immigrant nations, religious and ethnic minorities. In the 2019 Presidential Election, political primordialism became a selling point for politicians to win the battle that almost broke the defense of Indonesian unity. This paper concludes, strengthening primordialism in politics distorts democratic principles and poses a threat to the integrity of the nation state.
\end{abstract}

Keywords: Political Primordialism; Reformation; Indonesia.

\section{Introduction}

Many countries today are culturally diverse. Will Kymlicka said that only a small number of countries in the world have the same language (Will Kymlcka, 2002). This diversity has the potential to cause disunity if political homogenisation and hegemonization occurs. The collapse of Yugoslavia, the Soviet Union, Pakistan's independence from India is evidence of the failure to manage diversity which has led to the disintegration of a country. In contrast, Canada's experience of giving Quebec special autonomy, Spain's efforts to maintain Catalunya and the success of the United States to unify diversity become evidence that multiculturalism is not a problem, if managed properly.

Indonesia as a multicultural country faces the same challenges as other multicultural countries. Samuel P. Hutington's prediction in his book The Clash of Civilizations that predict multicultural states - not the exception of Indonesia - experiences symptoms of Balkanization that lead to divisions not fully proven, but communal conflicts in several regions in Indonesia at the beginning of reforms warn of the dangers of multiculturalism if not managed properly. The threat of division due to multiculturalism continues to haunt Indonesia despite entering a decade of reform.

The rise of ethnocentrism and ethnonationalism (Fadli Zon, 2002) sentiments in the regions is still a real threat to Indonesia. Agus Dwiyanto said that the implementation of decentralization was finally read as an opportunity to fight for indigenous people (local) as holders of power in government (Agus Dwiyanto, 2002). Nordholt also saw this symptom, 
according to him after the reform and decentralization in Indonesia led to attitudes that "favor" the local people to encourage the removal of minority groups in a particular region (Henk Schulte Nordholt, Gerry Van Klinken, 2007). Therefore, not surprisingly, various ethnic conflicts in Kalimantan, Maluku and Sulawesi and in several other places in Indonesia are evidence of the 'gray side' of decentralization (Martin Ramstedt dan Fajar Ibnu Tufail, 2011). In the national stability paradigm, this case clearly has a tendency as a national danger.

After ten years of reformation, primordialism has overshadowed political competition in the last three years in Indonesia, preceded by mass actions in Jakarta which rejected AHOK. Rejection of AHOK - based on rude attitude, language that speak out frankly, policies that are not populist, mingled with rejection of ethnic minorities (Chinese) and minority religions (Christians), where AHOK is considered unfit to be the regional head who leads the majority group (native to Indonesia and Islam) - illustrates the practice of political primordialism. This phenomenon of political primordialism continued until the 2019 simultaneous elections which formed at least two power groups, those considered Islamic (Prabowo-Sandi) and less Islamic (Jokowi-Maruf Amin), nationalists and communists, radicalism and pluralism, and various other differences. The mixing of politics and primordial ties then triggered the polarization of the 2019 elections simultaneously becoming sharper and almost dividing the defense of the Indonesian nation. Based on this phenomenon, this paper aims to describe the practice of political primordialism in the reform era.

In Indonesian literature, the term primordial was first coined by an American anthropologist, Clifford Geertz in the 1960s. Geertz who studied the people of Indonesia and other developing countries produced a work entitled, "The Integrative Revolution, Primordial Sentiments, and Civil Politics in New State". The contribution of the book is that primordial ties are often a factor in the birth of political conflict in new countries, including Indonesia. According to Clifford Geertz (Clifford Geertz, 1991), the people of new, multi-ethnic, multilingual and sometimes multi-racial nations tend to judge instantaneous, concrete and 'natural' groupings ... as substantive content about their personalities. respectively. Group solidarity greatly influences the political conflict that can develop.

Geertz said that the source of group solidarity is the primordial bonds that form the glue of the primordial groups concerned. According to Geertz, in the new State although class loyalties (economic strata) still exist, but this loyalty is defeated by primordial loyalty. Geertz, sees that new (developing) countries generally lead to serious inequality due to primordial ties.

"Primordial ties here are interpreted as feelings born from what is" thought to exist "in social life: a large part of direct relationships and family relationships, but also includes membership in certain religious environments, certain languages or dialects and certain social habits" (Clifford Geertz, 1991).

According to Geertz, in modern society, increasing primordial ties as something that must be avoided, so that national unity efforts are created by blurring these ties. While in societies undergoing a process of modernization, national unity is carried out by strengthening these primordial ties, however it does not pay attention to the weak national political traditions and technical prerequisites of governance that can realize prosperity. As a result, the cremation of conflicts between primordial ties and national ties triggers problems of ethnicity, regionalism, adherence, and so on. Or in simple language it can be said that political conflict is caused by a confusion between political loyalty and primordial loyalty.

Geertz identified six differences that triggered primordial shock, namely: first, blood relations (ethnicity), namely limitation that is kwasi-familial due to biological relations. Second, the type of nation (race) which is characterized by physical form such as skin color, face shape, height, hair shape, and others. Third, language. Fourth, regional / regionalism 
(regionalism) viewed from geographical location. Fifth, religion. Sixth, habits identified with intellectual and artistic groups who feel they are bringing civilization. This primordial bond gave birth to primordial sentiments and primordial loyalty.

\section{Result and Discussion}

\subsection{Political Primordialism in Indonesia}

Indonesia as a multicultural country has been clearly seen from the Indonesian motto 'Unity in Diversity'. This motto implies that the Indonesian people are very diverse, but are bound in a unity that is bound by a shared identity. In Soekarno and Hatta's thinking, that bond was called nationalism. Nationalism, according to Sukarno, was a bond based on the same goals and feelings of the same fate of the Indonesian people who were colonized and wanted independence. While Hatta said Indonesian nationalism was based on a long process of historical evolution over the unification of different nations (cultural unification). In contrast to Sukarno and Hatta who saw the formation of nationalism based on shared feelings and historical processes, Beneddict Anderson called the ideology of nationalism not something real, but an imagined idea (imagined comunity).

The multiculturalism will become a concern in building a nation if it is managed well, but it can also potentially lead to conflict on the basis of strengthening primordialism. In Agusmawanda Jafar's study the rise of primordial ties in Indonesia was triggered by the problem of distribution of political and economic resources. He cited the case of Kartosuwiryo, the leader of Darul Islam in West Java and Kahar Muzzakar in South Sulawesi, triggered by the inability to accommodate political resources. Meanwhile, priomordialism in the democratic era of Pancasila (Soeharto) was triggered by ethnic and regional political hegemony. Javanese ethnicity that dominates power, gave rise to inequality between Java and outside Java, thus triggering a division between Java and Outside Java. This is further strengthened by the policy of uniformity (sep: naming villages) as a result of the centralization policy. Furthermoreprimordialism in the reform era was triggered by political competition in elections (Agusmawanda Jafar, 2017).

Political primordialism in elections is almost found in every region in Indonesia. Mobilization by exploiting ethnic and religious politics in Indonesia was once expressed by Supriatma (Antonius Made Tony Supriatna, 2009). In the East Sumba Regional Election, two candidates for the Bupati, Umbu Mehang Kunda and Lukas Kaborang, used cultural and religious symbols to mobilize popular support to become the Regent of East Sumba in 2005 (Indonesian, 2005). Ahmad Dahlan, a native Malay, succeeded in winning the election of the Mayor of Batam. Ahmad Dahlan's success is determined by his ability to use Laskar Hulubalang Putih, an ethnic Malay militia with a membership of around 10,000 people in influencing the people of Batam (Framework \& Choi, 2007). In Southeast Sulawesi, in the 2008 Governor Election, the Tamalaki Circle of Friends became one of NurAlam's loyal supporters. In its journey, Tamalaki not only became NurAlam's success team, but also became the guardian of various government policies. For those who disturb NurAlam, they will be confronted by the Tamalaki group, because NurAlam is seen as a representation of the Tolaki people (Universitas \& Oleo, 2015).

Political primordialismwas also found in the direct election of regional heads in Kendari City. The Zuada Study (2012) found that in the 2007 and 2012 elections, each candidate chose a partner to pay close attention to ethnic representation. 
Table. 1. Candidate Mayor of Kendari In the local elections of 2007

\begin{tabular}{clcc}
\hline \multicolumn{1}{c}{ Name } & Party & Ethnic \\
\hline 1. & Musakir Mustafa-Ridman & Golkar & Bugis-Tolaki \\
2. & Asunawas & PPP & Tolaki-Muna \\
3. & Asrun-Musadar Mappasomba & Tolaki-Bugis \\
& PBS,PPDK, Partai Demokrat, & Penegak Demokrasi \\
Indonesia (PPDI) & PBB, PAN & Tolaki-Bugis \\
4. & Baharudin Aboe Kasim-Yani & & \\
& Kasim Marewa & PDI.P & Tolaki-Muna \\
5. & Jusuf Ponea-Laode Khalifa & &
\end{tabular}

The importance of ethnic variables as a means of mobilizing support in Kendari City took place again in the 2017 elections, three pairs of candidates in choosing a partner one of them considered ethnic factors.

Tabel. 2. Candidate Mayor of Kendari In the local elections of 2017

\begin{tabular}{clccc}
\hline No & \multicolumn{1}{c}{ Name } & Party & Ethnic \\
\hline 1 & Abdul Razak-Haris Andi & Golkar dan Nasdem & Tolaki/Bugis \\
& $\begin{array}{l}\text { Surahman } \\
2\end{array}$ & $\begin{array}{l}\text { Adriatma Dwi Putra-Sulkarnain } \\
3\end{array}$ & PAN, PKS, PKB, PBB, PKPI & Tolaki/Bugis \\
& $\begin{array}{l}\text { M. Zayat Kaimuddin-Suri } \\
\text { Syariah M. }\end{array}$ & PDI.P, Demokrat, Hanura, & Muna/Tolaki \\
& & PPP. & \\
\hline
\end{tabular}

Source: Najib dan Zuada, 2019.

Political primordialism in Kendari City re-emerged in early 2019, the slow process of nominating vice mayor of mayor of Kendari triggered a mass movement on behalf of Tamalaki urging the Mayor of Kendari, Sulkarnain to immediately establish Siska Karina Imran as a candidate for deputy mayor (Zonasultra, 2019). In the demonstration, primordialism attitude slipped in the demands of the demonstrators and in the Sultrawatch social media talks. Political primordialism also occurs in Palu City, Central Sulawesi. In the study of Ilyas Lampe, ethnic identity is used by politicians to gain political advantage (Lampe, n.d.). Political primordialism appears to be very prominent in the 2017 Jakarta Regional Head Election,Ahok who came from ethnic and religious minorities received rejection from a number of Islamic organizations which reached its peak at the birth of the 212. movement. This 212 people re-involved themselves in the 2019 Presidential Election battle, which gave rise to a stigma that nuanced primordialism.

\subsection{The Impact of Political Primordialism}

Basically there is nothing wrong with primordial ties because everyone does not have the choice to be born into a tribe, religion, region, or with a particular mother tongue, but the problem then is to make the primordial bond as a political instrument to gain political support. When primordial ties are used as political instruments, they will inevitably clash with other people's primordial ties, thus political conflicts for primordial reasons are very likely to occur.

Fanaticism that arises from primordial bonds is inherent and difficult to displace, so primordial bonds are often used as effective instruments by actors to achieve political goals. 
Because with primodial ties can give birth to primordial loyalty, political actors in achieving power utilize these instruments to gain political power. In addition, primodial bonds do not require more energy in the process of understanding, because they exist and are inherent in everyone. Therefore, for "instant" political actors will choose the bond because it is more effective and efficient to get political support as has happened in the political context at the regional and national levels lately.

The use of primordial ties for political purposes has the potential to create political turmoil because there will be a mixture of loyalty, that is, political loyalty and primordial loyalty (Maswadi Rauf, 2001). There are three effects of mixed primordial loyalty. First, loyalty that is born from the results of this combination is political loyalty that is "blindly", meaning that support as a consequence of loyalty and leaders is no longer based on objectivity "right-wrong or able or unable", but rather because of personal ties concerned good because; ethnicity, religion, line of education and even regional origin. Support is not due to the ability of the leader who can be assessed rationally, but it will be more on the similarity of primordial aspects.

Secondly, a mixture of political and primordial loyalties results in the difficulty of separating between political and primordial issues, as was the case with Ahok in DKI Jakarta. Third, another effect of the mixed political and primordial allegiance is that political leaders have the potential to shift political issues into primordial issues in order to obtain maximum support in a fast tempo. For example, the bad image that has so far hit parties with Islamic ideology backgrounds because some of the party's top officials are involved in cases, often diverting issues. There is an assumption that the case that hit them is by design, because there are other forces that do not want Muslims to help manage and improve this nation.

Primordialism also poses a threat to the democratic process, namely competition, participation and political freedom. First on the competition dimension, the inclusion of primordial issues in the arena of competition is a serious money threat, because it will affect the degradation of the basic values of the competition itself. Ideally a political competition is a gambling of political ideas to achieve the name of the common good or the common good (the good life) as the political understanding of Plato and Aristotle. However, the inclusion of primordial issues in the political arena shifts the stakes of political ideas, into stakes of identity with ethnic / ethnic, religious and regional backgrounds. Thus the competition does not capture those who have an idea of the common good, but rather those who represent certain primordial groups. So that the ideal aspect of political competition is to capture the best political leaders with a variety of "rational choice" considerations shifted to "sociological models" with a primordial background.

Second, on the aspect of participation. Good democracy can be seen in high and autonomous citizen participation. Conversely, low citizen participation and mobilization can be categorized as poor. The use of primordial issues to attract citizen participation is very dangerous and classified as very traditional. This method is often used by politicians who are poor in ideas but want to win the fight. Third, political freedom. Not infrequently in the electoral process, candidates gather primordial forces to get rid of political competitors. The use of big name alumni, organizations, flags, ethnicity, religious sects is a barrier for those from different groups. This indirectly limits the range of motion and closes the gap for more competitive battles. 


\section{Conclusion}

Political primordialism is not only a substantive threat to democracy, but also a threat to the integrity of the nation state. Primordial bonding is an inevitable fact because God basically created his creatures are not entirely the same. However, primordial ties are very dangerous, if mixed with political loyalty. Therefore, it is important for politicians not to use identity instruments to win competition. Instead, politicians need to develop ideas, creativity and a spirit of sportsmanship.

\section{Reference}

[1] Agus Dwiyanto, E. al. (2002). Reformasi Tata Pemerintahan dan Otonomi Daerah. Yogyakarta: PSKK.

[2] Agusmawanda Jafar. (2017). Primordilalisme Politik Pada Pemilihan Kepala Daerah. Makassar: Universitas Hasanuddin.

[3] Antonius Made Tony Supriatna. (2009). Menguatnya Kartel Politik Para Bos. $\begin{array}{lllll}\text { PRISMA, } & 28, & \text { No. } & 2 . & \text { Retrieved }\end{array}$ https://www.prismajurnal.com/issues.php?id=7d17c768-56be-11e3-a6cc429e1b0bc2fa\&bid=2645f9ba-56b8-11e3-a6cc-429e1b0bc2fa

[4] Clifford Geertz. (1991). Ikatan-Ikatan Primordial dan Politik Kebangsaan di Negara-Negara Baru, dalam Pembangunan Politik dan Perubahan Politik. Jakarta: Yayasan Obor Indonesia.

[5] Fadli Zon. (2002). Gerakan Etnonasionalis. Jakarta: Sinar Harapan.

[6] Framework, I., \& Choi, N. (2007). With Compliments. (137).

[7] Henk Schulte Nordholt, Gerry Van Klinken, I. K. H. (2007). Politik Lokal di Indoensia. Jakarta: Yayasan Obor Indonesia.

[8] Indonesian, T. (2005). P ilkada in E ast $S$ umba: $A n O$ ld $R$ ivalry in a $N$ ew $D$ emocratic $S$ etting Jacqueline Vel 1. 80(June).

[9] Lampe, I. (n.d.). Identitas Etnik dalam Komunikasi Politik. 299-313.

[10] Martin Ramstedt dan Fajar Ibnu Tufail. (2011). Kegalauan Identitas. Jakarta: PT. GRASINDO.

[11] Maswadi Rauf. (2001). Konsesus dan Konflik Politik: Suatu Penjajakan Teoritis. Jakarta: Direktorat Pendidikan Tinggi Departemen Pendidikan Nasional.

[12] Universitas, D., \& Oleo, H. (2015). HEGEMONI POLITIK NUR ALAM DI SULAWESI TENGGARA THE PHENOMENON OF ' LOCAL BOSSISM' IN THE DECENTRALIZATION ORDER: THE STUDY OF NUR ALAM POLITICAL HEGEMONY IN SOUTHEAST SULAWESI Eka Suaib dan La Husen Zuada Reformasi politik pasca jatuhnya rezim Soeharto. 51-69.

[13] Will Kymlcka. (2002). Kewarganegaraan Multikultural. Jakarta: LP3ES. 